LINGÜÍSTICA 



\title{
LA COMUNICACIÓN NO VERBAL EN LOS PRIMEROS DÍAS DE LA CONQUISTA AMERICANA
}

\author{
Rita Jáimez Esteves
}

\section{(c) $(7)$}

Esta obra está bajo una licencia Creative Commons Reconocimiento-No Comercial-Sin Obra Derivada 



\title{
LA COMUNICACIÓN NO VERBAL EN LOS PRIMEROS DÍAS DE LA CONQUISTA AMERICANA

\author{
NON-VERBAL COMMUNICATION IN THE EARLY DAYS OF THE \\ AMERICAN CONQUEST
}

\begin{abstract}
RESUMEN
El hombre procura comunicarse en cualquier circunstancia, ni la ausencia de una lengua común se lo impide. Eso fue lo que ocurrió cuando Colón llegó a América. Ni extranjeros ni nativos conocían la lengua que oían; sin embargo, se explicaron, departieron e intercambiaron realidades de ambos mundos. El presente trabajo exponemos tres formas de comunicación no verbal empleadas por aquellos días: las señas, los intérpretes y las ilustraciones. Las dos primeras se utilizaron para que hubiera diálogo en América. La última sirvió para informar a los europeos cómo era el Nuevo Mundo. Explicamos el rol de las señas y de los intérpretes, primordialmente, a través del Diario colombino. Para abortar la utilidad de las imágenes, nos apoyamos esencialmente en Galeotto Cei y su Viaje y descripción de las Indias, 1539-1553. Las fuentes consultadas ciñen territorialmente el estudio a las Antillas y a la zona conocida actualmente como Venezuela.

Palabras clave: comunicación no verbal, señas, intérpretes, ilustraciones, conquista americana.
\end{abstract}

Rita Jáimez, Esteves

\begin{abstract}
Over the centuries, mankind tried to communicate with each other in all circumstances of life, and although there is not a common language shared by all members of the world, there is a constant flowing of information. In order to illustrate this perspective, let us take into account Christopher Columbus arrival to America, in which two languages collide. Neither foreigners nor native knew the language they were hearing; however, they dialogued. The following work presents how signs, illustrations and their interpreters allowed communication in the first days of the American conquest. It also revises several chronicles, mainly in the Antilles and Venezuela, based on Christopher Columbus' Diary and Galeotto Cey's (1539-1553) Viaje y descripción de las Indias.

Key words: non-verbal communication, signs, interpreters, illustrations, American conquest.
\end{abstract}

\section{La humanidad y su necesidad de comunicarse}

No hay humanidad sin comunicación porque el hombre no existe en soledad. Su condición de ser social así lo impone. Aun desde antes de su origen, necesita del otro; esto es: de compartir con el otro, de informarle al otro, de solicitarle al otro, de preguntarle al

\footnotetext{
Rita Jáimez Esteves. Universidad Pedagógica Experimental Libertador. Profesora Catedrática. Miembro del Instituto Venezolano de Investigaciones Lingüísticas y Literarias Andrés Bello (Caracas-Venezuela). Jefa de la Cátedra Estudios diacrónicos socio-geográficos y del español. Venezuela.

Correo electrónico: ritamje@gmail.com
}

Recepción: 07- 10- 2013

Aceptación: 07- 11- 2013 
otro. Proveerse de alimentos y de seguridad fueron necesidades básicas cubiertas por algún pasado del homo sapiens, acaso por el homo habilis. Pero para que hoy llegara hasta aquí el sapiens requirió y logró comunicaciones más complejas. El homo sapiens activó un proceso de la comunicación para avisarle al otro sapiens que se cernía un peligro y juntos decidieron cómo evitarlo; ideó otro modo para informarle cómo mejorar la calidad de los alimentos y su interlocutor lo acompañó en el desarrollo de la idea y consiguieron más nutrientes, aun en las condiciones más extremas.

Para la especie humana, debió de ser imperiosa la necesidad de interaccionar, puesto que modificó su estructura en procura de la comunicación verbal. Probablemente, hace 500000 años comenzó a mutar hacia el habla y la nueva estructuración se había consolidado hace 5000 . La lengua se hizo más gruesa que la de los monos y antropoides, la postura erguida mejoró la ubicación de las cuerdas vocales; el paladar se atrasó y la laringe descendió dentro de la garganta. Así pues, para hablar, el humano alteró y usa órganos cuyas funciones primarias son digestivas o respiratorias (cfr. Laitman, 1985 y Salmones-Castañeda, 2008).

Por medio de la comunicación, el homo sapiens llegó más allá. Tuvo acceso al mundo que lo circunda y lo modificó para su propio beneficio; por ello, la comunicación se presenta como vital para la preservación y evolución de la vida humana. En la medida en que la comunidad humana advirtió que sabía, generó más complejos sistemas comunicativos y multiplicó su deseo de informar quién es a conocidos y desconocidos y hasta a destinatarios hipotéticos.

Disímiles generaciones, por ejemplo, han pretendido comunicarse con las futuras mediante cápsulas de tiempo, o sea, colocando en lugares estratégicos un tipo de recipiente hermético, elaborado con algún material imperecedero, contentivo de objetos que le indicarán a su descubridor qué grupo cultural lo dejó, quién era, cómo vivía, qué hacía, cuáles eran sus intereses, cómo se identificaba, cuáles eran sus singularidades, etc. Con ello, cada agrupación ha pretendido informar al porvenir su paso por el mundo. Veamos algunos intentos. El Poema de Gilgamesh escrito en una de las tablas sumerias hacia el año 2000 a.C. refiere una cápsula del tiempo, que una cultura había depositado 5000 años antes. El 5 de diciembre de 2009, en Madrid se descubrió un cofre hecho de plomo, enterrado el 11 de diciembre de 1834 (Bécares, 2009). Contenía “cuatro tomos del año 1819 del Quijote, un libro de la vida de Miguel de Cervantes y otras publicaciones, como textos legislativos, manuscritos y varios paquetes con objetos sin identificar" (Bécares, 2009). Los especialistas resaltan otros intentos del segundo cuarto del siglo XX. En 1939, entre las actividades organizadas en la Exposición Universal de Nueva York, se enterró una cápsula del tiempo que debe de develarse transcurridos cinco mil años, en 6939. Ese mismo año se enterró en Atlanta la denominada Cripta de la civilización para abrirse en 8113 (Rodríguez-Flores, 2002; Phail-Fanger, 2009). A medida que se aproximaba el final del milemium los proyectos se multiplicaron. Hasta algunos medios de comunicación tan prestigiosos como New York Times y ABC News se embarcaron en la empresa. En Latinoamérica, en el marco del bicentenario de la independencia, México y Argentina también han hecho sus ensayos. Para el año 2009, Phail-Fanger conjeturaba más de 10000 cápsulas del tiempo en todo el orbe. Actualmente también se hallan unas cuantas cápsulas virtuales en Internet. Suponemos que en estos momentos el número calculado por Phail-Fanger se quedó corto.

En nuestro presente, las redes sociales demuestran que nuestra necesidad de comunicación se mantiene. Ahora sin límite físico alguno, todos los habitantes del planeta 
podemos darnos a conocer en isocronía. Tomemos a facebook como modelo de ello. Se trata de un sitio web de redes sociales que permite que amigos entre sí y que un amigo de un amigo se conecten y se conozcan. En este espacio se intercambian fotografías, enlaces y textos. Para el 2011, superaba los quinientos usuarios y esta cifra debió incrementarse con el paso de los meses. Probablemente, por su fácil manejo y sus diversas posibilidades audiovisuales, lo utilizan para comunicarse individuos de distintas edades, culturas, géneros e intereses. En la actualidad se traduce en más de 70 idiomas y personas de más de 180 países desarrollan aplicaciones para que esta herramienta de intercambio virtual continúe enriqueciendo sus aplicaciones (Llorens-Cerdà y Capdeferro-Planas, 2011).

Pero no solo nos interesa comunicarnos entre nosotros como especie, adicionalmente, hemos necesitado y necesitamos comunicarnos con entidades de otros mundos. Propuestas hechas para la comunicación en la galaxia conocemos desde el siglo XIX. Unas, que podrían parecernos extravagantes en el presente, se hicieron en un mundo -resaltamos- que desconocía la electricidad y las ondas radiofónicas. Por aquella época, hubo quien planteó un triángulo pitagórico en los bosques de pino de Siberia; asimismo, hubo a quien se le ocurrió construir unos 40 kilómetros de trincheras en el Sahara, rellenarlos de querosén y encenderlos y también hubo quien prefirió disponer una extensa red de reflectores solares. Pretendiendo comunicaciones intergalácticas, individuos del siglo XX idearon otros recursos sobre la base del mismo principio de las cápsulas. La sonda Pioneer 10 fue lanzada en 1972 y al año siguiente se envió la Pioneer 11. En 1974 a través de radio radiotelescopios se despachó el conocido mensaje de Arecibo. En 1977, se dispararon las Sondas Voyager I y Voyager II. Llevan discos con música, fotografía y saludo en más de 60 idiomas (cfr. Rodríguez-Flores, 2002 y Phail-Fanger, 2009). Las investigaciones en el campo continúan y han recibido grandes cantidades de dinero de muchas empresas privadas, lo que señala que, definitivamente, a la especie humana le interesa comunicarse o dejar rastro de su existencia. La civilización actual ha adquirido mucho conocimiento, ha avanzado mucho, pero sigue necesitando comunicarse, no ha renunciado a compartir ideas, sueños, intereses, identidad, con humanos o no, del pasado y del futuro.

\section{Objetivos de este ensayo}

Arriba apreciamos que aunque la comunicación humana generó el lenguaje verbal, hay otros medios de comunicación. Este es apenas uno más. De hecho, Davis (1970) juzga que la palabra es el último recurso comunicativo, que el hombre acude a ella cuando todo lo demás no le funciona; Martínez-Díaz (1997) asegura que la postura, el tono, cómo manipulamos un objeto dicen más que las palabras. A este parecer, hace medio siglo Birdwhistell (1952) le asignó porcentajes a estos pareceres. Aseveró que solo el 35\% del lenguaje humano se alcanza con la palabra; que a la entonación le corresponde el $38 \%$ y que el resto se expresa con la actitud corporal.

Como se aprecia, no debemos confundir comunicación con lenguaje verbal. La comunicación no se agota en esta clase de lenguaje. Mucho logra manifestar el hombre actual sin oralidad. Si bien el deseo de comunicar condujo al lenguaje articulado, en modo alguno, este ha sido el único medio que tenemos o al que hemos acudido para comunicarnos, para interaccionar con otros, para encontrarnos en el otro. El hombre ha ideado múltiples formas de comunicación, además de la verbal, porque siempre supera las barreras lingüísticas, usa su inteligencia para ello. El hombre como ser social se define, se hace, se construye en la comunicación. De hecho, ¿cuántos medios hemos inventado para comunicarnos? 
Si en circunstancias ordinarias necesitamos interaccionar, proyectémoslo ahora en un escenario tan extraordinario como el que acaeció el 12 de octubre de 1492. En aquellas calendas todo era nuevo, poco se conocía y mucho se ignoraba. Consiguientemente, hacer partícipe al otro de quién se es, de dónde se proviene, cuál es el origen, qué se hace, qué se busca, qué se quiere, cómo se hará, cómo se organiza socialmente, etc., fue necesidad inmediata de parte y parte. De cómo se comunicaron estos seres que no tuvieron un idioma común se trata este estudio, de responder cómo los hombres que protagonizaron el encuentro de los dos mundos interaccionaron a pesar del bloqueo lingüístico. Como en las primeras horas el lenguaje articulado no tuvo cabida, la comunicación no verbal se impuso. Pero cómo se dio, a qué vehículo se acudió, cuáles fueron sus características, quién lo uso, para qué y otras preguntas afines serán respondidas en este texto. Específicamente, el artículo expone tres formas de comunicación no verbal ${ }^{1}$ que emplearon los europeos en los primeros días de la conquista americana: las señas, los intérpretes y las ilustraciones.

Para efectuar la tarea, acudiremos a los escritos de los protagonistas del momento. Para inquirir el rol de las señas y de los intérpretes revisaremos algunos textos colombinos: el Diario y sus Carta-relación (1402-1503). Para escrutar el empleo de las ilustraciones examinaremos básicamente Viaje y descripción de las Indias (1539/1553) de Galeotto Cei. Auxiliarán y complementarán estos alegatos, otros testimonios que, aunque de fecha posterior, se detienen más en el proceso de exploración que en el de población: Américo Vespucio (1504), Gonzalo Fernández de Oviedo y Valdés (1525), Titus Neukomm (1535), Nicolás Federmann (1557), Jerónimo Benzoni (1565), Juan de Castellanos (1589), Pedro de Aguado (1581), Pedro Simón (1627), José Gumilla (1745). Por otro lado, señalamos que este estudio de la comunicación no verbal se circunscribe a las Antillas y al territorio conocido actualmente como Venezuela.

\section{Las señas}

El hombre blanco debió arreglársela para subsistir en ese territorio inhóspito. Tenía que alimentarse, vestirse, abrigarse. Después de cubrir sus necesidades básicas, debía constatar a qué se enfrentaba política, militar y territorialmente. Hacerlo pasaba no solo por indagar y retirarse discretamente, sino por preguntar y constatar con los aborígenes. Esto es: comunicarse.

Dado que el primer contacto se hizo de inmediato, necesitaron comunicarse desde el principio. El jueves 11 de octubre, alrededor de las 10 de la noche, Colón y su gente buscaban determinar si habían encontrado tierra, verificar si en realidad habían visto "lumbre". Dos horas después de la media noche lo confirmaron: habían tropezado con tierra. Eran las primeras horas del viernes 12 de octubre. Con la luz del sol, las dos civilizaciones se reunieron. Europeos y nativos se encuentran. Hay ganas, deseos y necesidad de decirse cosas, de comunicarse, de contar, de preguntar y de responder, de informar y de saber. No obstante, cuando se oyeron se ven sitiados lingüísticamente.

En el primer viaje colombino se embarcaron dos intérpretes (Varela, 1986), mas no pudieron ejercer su plaza, de nada les valieron sus dotes de políglotas: se enfrentaron a lenguas nunca antes oídas. El verbo no les servía. Entonces ¿en qué lengua hablar? ¿Cómo hacerse entender? ¿Cómo fueron los primeros contactos? Mientras conseguían algún intérprete eficiente, ¿cómo se enteraban?, ¿cómo se la arreglaban para avanzar?, ¿cómo decir?, ¿cómo preguntar?, ¿cómo saber? 
Recurrieron a los gestos: los sobrecargaron. Las manos y las señas se llenaron de expresividad. La ausencia de una lengua común no evitó el entendimiento. En su Diario, el Almirante una y otra vez testimonia este recurso comunicativo:

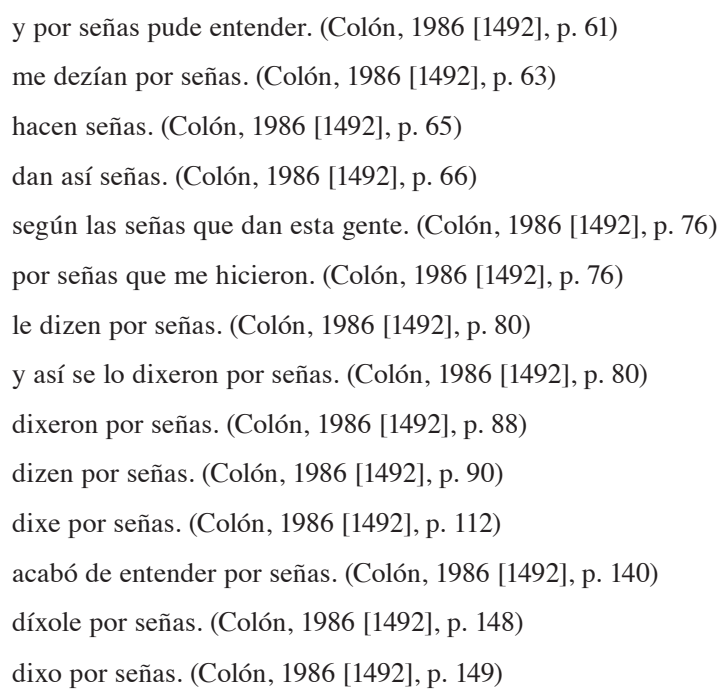

Predomina el verbo “decir" en los ejemplos citados. Los interlocutores dijeron a través de señas. Las señas y los gestos acompañados de palabras fueron la esencia de los primeros encuentros. "Estaban 'mudos' de voz, pero no mudos de manos y brazos y piernas, no mudos de expresión" (Martinell-Gifre, 1992, p. 128). Con las manos, con las señas mucho dijeron. Este es el principal recurso, lo reportan distintos cronistas posteriores a Colón. A continuación exponemos una muestra de ellos.

Américo Vespucio contó que se enfrentaron a un grupo de indígenas un día del mes de junio, el cual huyó cuando se vio perdido, dejando abandonados a cuatro prisioneros que "dijeron por señas [cursiva agregada], que los habían castrado para comérselos" (Vespucio, 1962 [1504], p. 56). Años más tarde, el alemán Nicolás Federmann señaló que para comunicarse con tres indios cyparicotes debió conformarse con hacerles señas: "desgraciadamente no tenía ningún medio de hablarles, pero les hice entender por señas [cursiva agregada] que no queríamos maltratarlos" (Federmann, 1955 [1557], p. 151 y s.). Casi una década después, Jerónimo Benzoni apuntó que los nativos de Cubagua se comunicaron por señas con el Almirante, incluso, rememoró que a través de señas le informaron dónde encontraría perlas:

(1) Los nativos [...] en el mejor modo que encontraron, expresándose por señas, [cursiva agregada] trataron de persuadir al Almirante para que bajase a tierra. (Benzoni, 1962 [1565], p. 13)

(2) El Almirante, tan hábilmente como pudo, le preguntó por el lugar de las perlas, y por señas le indicaron [cursiva agregada] las playas de Cubagua donde las pescaban. (Benzoni, 1962 [1565], p. 13)

Bartolomé de Las Casas en su tiempo también recordó la utilidad de las señas:

(3) Hiciéronles los cristianos señas [cursiva agregada] de amistad [...] y con las manos haciendo señas. (Las Casas, 1962 [1566]), p. 146)

(4) [Los cristianos querían] darles a entender que no les querían hacer mal, por señas. [cursiva agregada] (Las Casas, 1962 [1566]), p. 146 y s.)

(5) Lléganse a los cristianos, y poco a poco pierden el miedo, y por señas les dicen [cursiva agregada] que aquellas chozas no son sus casas principales. (Las Casas, 1962 [1566]), p. 147) 
Los diferentes extractos prueban que unos y otros miembros de grupos diferentes, de grupos humanos que nunca antes se habían visto y cuya existencia ignoraban hasta ese entonces, querían saber y debían comunicarse. Asimismo, sirven para certificar que los gestos fueron protagonistas desde los momentos iniciales. El emisor realizaba la seña, pero lo más importante es que el receptor las comprendió; de modo que hubo diálogo, comunicación, entendimiento. Dos culturas, dos mundos se encontraron, se acercaron mediante señas.

Seguramente, con sus menos y sus más, estos primeros cruces dialógicos estuvieron saturados de gestos acompañados de muchas palabras dichas en tono alto, muchas de las cuales caían en oídos sordos. Únicamente ruido percibían estos oyentes. Expertos ya han explicado la situación: cuando dos personas con idiomas diferentes intentan cooperar en la interacción, en el plano de la fonología acuden a un "tono más alto, la entonación más exagerada y su amplitud tonal es mayor" (Larsen-Freeman y Long, 1994, p. 107). Ocurrió ayer, ocurre hoy y ocurrirá mañana, puesto que es lo que sobreviene cada vez que dos individuos con dos lenguas diferentes necesitan y están dispuestos a hacer cosas con las palabras. Desde el punto de vista pragmático hacían cosas con las señas: informaron, declararon, prometieron, etc. Dos motivaciones básicas guiaron estos encuentros comunicativos: a los visitantes (o invasores) les interesaba sobrevivir (saciar el hambre y la sed, protegerse de las calamidades climáticas y de los animales o posibles enemigos) y los anfitriones querían la tecnología foránea que se concretaba en objetos en buenas o malas condiciones: platos enteros o rotos, espejos íntegros o quebrados, vestimenta en buen o mal estado, etc. En efecto, el trueque logrado evidenció comunicación satisfactoria, la cual se concretó con más señas que palabras: "Entendiendo los indios algo de esto, mejor por las señas que por las palabras” (Simón, 1992 [1627], p. 234).

Ambos grupos hicieron su mayor esfuerzo para comunicarse, por esta razón, se presupone que llenaron, tanto como pudieron, los gestos de significado y de expresividad. Los navegantes estaban extenuados y tenían hambre. Y las tribus tenían el sustento y todo lo que podían requerir. Los europeos satisficieron sus necesidades básicas, fueron alimentados y cobijados: "Comenzaron a tratarse y comunicarse más sin miedo los unos con los otros por el camino de trueque y rescate" (Simón, 1992 [1627], p. 235). Esto lo comunica, nuevamente, el Almirante en su Diario, por ejemplo, en las anotaciones que realizó el 16 de octubre:

(6) Enbié el batel de la nao en tierra por agua; y ellos de muy buena gana le enseñavan a mi gente adónde estava el agua, y ellos mesmos traían los barriles llenos al batel y se folgavan mucho de nos hazer plazer. (Colón, 1986 [1492], p. 67)

Al principio recibieron comida y agua. Luego preguntaron los visitantes por los objetos de valor que los indios ostentaban sin petulancia alguna. Como respuesta inmediata comenzó el trueque y el rescate. El Almirante así lo manifiesta en su Diario el sábado 13 de octubre: "nos traían papagayos y hilo de algodón en ovillos y azagayas y otras cosas muchas, y nos las trocavan por otras cosas que nos les dávamos, como cientezillas de vidrios y casaveles" (Colón, 1986 [1492], p. 59). Trascurridos tres días, la transacción era práctica cotidiana:

(7) Nos traían agua y de lo que tenían. Yo a cada uno le mandava dar algo, es a saber, algunas contezillas, diez o doze d'ellas de vidrio en un filo, y algunas sonajas de latón d'estas que valen en Castilla un maravedí cada una, y algunas agujetas, de que todo tenían en grandíssima exçelençia, y también les mandava dar para que comiessen cuando venían en la nao, y miel de açucar. (Colón, 1986 [1492], p. 67)

Y las señas cumplían muy bien su función: comunicaban, informaban. Colón se sentía complacido de ese potencial humano.

(8) Creo que, si es así [...] por señas que me hicieron todos los indios dista islas como por señas que llevo yo en los navíos, porque por lengua no los entiendo. (Colón, 1986 [1492], p. 77) 
Se entendieron con señas. Los grupos entendieron que el otro quería lo que no tenía. Los nativos entregaron alimentos, fauna y oro, y los visitantes agujas, vidrios, espejos y cascabeles. Las necesidades básicas y los objetos concretos sirvieron como primer puente de comunicación. El conocimiento de lo que significa un viaje y de las necesidades que surgen luego de hacerlo, les permitió a los indígenas presuponer qué requerían los extranjeros: agua y comida. Posteriormente, tener los objetos cerca, señalarlos sirvió para que cada quien supiera lo que deseaba el otro. Veamos cómo se apoyaron en la señalización de los objetos:

(9) Yo le vide algunas que tenían señales de feridas en sus cuerpos, y les hize señas qué era aquello, y ellos me amostraron [cursiva agregada] cómo allí venían gente de otras islas que estavan acerça y les querían tomar y se defendían. (Colón, 1986 [1492], p. 60)

(10) Mostraron la canela y pimienta y otras espeçias qu'el Almirante les avía dado, y dixéronles por señas que mucha d'ella avía cerca de allí al Sueste, pero que en allí no sabían si la avía. (Colón, 1986 [1492], p. 88)

(11) Mostró el Almirante a unos indios de allí canela y pimienta parez que de la que llevava de Castilla para muestra, y cognosciéronla, diz que, y dixeron por señas que cerca de allí avía mucho de aquello [...]. Móstroles [cursiva agregada] oro y perlas y respondieron ciertos viejos que en un lugar que lamaron Bohío avía infinito y que lo traían al cuello y a las orejas y a los braços y a las piernas, y también perlas. Entendió más, que dezían que avía naos grandes y mercaderías, y todo esto era al Sueste. Entendió también que lexos de allí avía hombres de un ojo y otros con hoçicos de perros que comían los hombres. (Colón, 1986 [1492], p. 86)

En 9, 10 y 11 observamos la actualización del verbo mostrar. Los tres fragmentos evidencian que a través de la exposición de objetos concretos aquellos hombres accedieron al intercambio de información; es decir, activaron la comunicación ostensiva. Por otro lado, la cita 11 por sí sola añade otra información. No dice explícitamente que se actualizaron señas ni que se entendieron por señas como ocurre en otros segmentos y, sin embargo, recoge el desarrollo de una buena entrevista sin palabras. En síntesis: pregunté y me respondieron. Sabemos que era imposible que este diálogo se desarrollara con lenguaje verbal. Imperó el no verbal. Es la primera vez que ese indígena escuchaba la lengua castellana y es la primera vez que el europeo escucha la lengua taína. El Almirante muestra los objetos que le interesan: canela, pimienta, oro y perlas (10 y 11). Los indios con toda seguridad le señalan las partes de sus cuerpos (11). De la misma manera, apreciamos qué pregunta y qué entiende el interlocutor español. Las palabras eran huecas por lo que indudablemente resuelven las señas. Que se entendieron queda de manifiesto en los siguientes segmentos. En 12, se apreciará que la comunicación se dio como si hubiera una lengua común; en las citas siguientes, que las señas facilitaron el encuentro dialógico:

(12) El Almirante estava hablando con [aquel rey virtuoso]. (Colón, 1986 [1492], p. 148)

(13) Y por señas pude endenter que, yendo al Sur o volviendo la isla por el Sur, que estaba allí un Rey que tenía gran vasos d'ello y tenía muy mucho. (Colón, 1986 [1492], p. 61)

(14) [Toda esta tierra] llena es de muchas agua, según pudo entender de indios que consigo lleva, que tomó en la isla Guanahaní, los cuales le dizen por señas que ay diez ríos grandes y que con sus canoas no la pueden cercar en XX días. (Colón, 1986 [1492], p. 80)

(15) Dixeron por señas que antes de tres días vernían muchos mercaderes de la tierra dentro a comprar de las cosas que allí llevan los cristianos y darían nuevas del rey de aquella tierra, el cual, según se pudo entender por las señas que davan, q’estava de allí cuatro jornadas. (Colón, 1986 [1492], p. 84)

(16) Dezían los indios que en aquella isla avía minas de oro y perlas y vido el Almirante lugar apto para ellas y almejas, qu'es señal de’ellas. Y entendía el Almirante que allí venían naos del Gran Cam y grandes, y que de allí a tierra firme avía jornada de diez días. (Colón, 1986 [1492], p. 80)

(17) Porque los indios que traía le dixeron ayer martes que avría tres jornadas desde el río de Mares hasta la isla de Baneque, que se debe entender jornadas de sus almadías, que pueden andar 7 leguas. (Colón, 1986 [1492], p. 94) 
(18) Vide una casa hermosa [...] y entré en ella y vide [...] colgado al çielo d'ella caracolas y otras cosas; yo pensé que era templo, y los llamé y dixe por señas si hazían en ella oración; dixeron que no. (Colón, 1986 [1492], p. 112 y s.)

Los ejemplos 12 y 13 manifiestan que hubo entendimiento, diálogo. Claro está, el europeo, simultáneamente, activó su marco del conocimiento; de hecho, dejó volar su imaginación y entendió lo que quiso. 14, 15 y 16 ofrecen datos numéricos y cronología occidentales. No sabemos cómo pudo el indígena informar las cantidades de ríos y de días, cuáles cifras utilizó; pero eso fue lo que quiso entender Colón. Se encontraron dos culturas y dos formas de ver el mundo, pero eso no impidió que mucho se contextualizara, se explicara. Por ejemplo, en 17 Colón refiere una distancia entre dos lugares en términos occidentales. En la cita 18 observamos cómo Colón decidió que una vivienda no se trataba de un templo y que en ella no oraban los nativos. ¿Cómo logró Colón saberlo? ¿Cómo el indígena pudo discernir qué era rezar? 16 confirma nuestras sospechas: El Almirante entendió que venían naves del Gran Can, pero este no forma parte del mundo americano, sí del mundo asiático. Le dio vida a un gran espejismo: hablaba de Japón y de las fabulosas riquezas que había referido Marco Polo. Hoy sabemos que el gran navegante falleció confundido, nunca supo o quiso reconocer que había tropezado con un mundo diferente al que salió a buscar.

\section{Las restricciones de las señas}

El orden del viejo mundo interpretó el nuevo. Colón incluso refirió el empleo de las señas como una manifestación positiva de las nuevas culturas. Dedujo del empleo que hacían de los gestos que eran buenos conversadores. He aquí todo lo que las señas indígenas le comunicaron al explorador.

(19) Dize que cree que en aquellas islas que avía visto deve aver cosa de valor, porque todas son grandes y tierras altas, valles y llanos, y de muchas aguas, y muy labradas, y pobladas, y la gente de muy buena conversación, aí como lo muestran sus gestos. (Colón, 1986 [1498], p. 262)

No obstante, hubo información que no se obtuvo realmente y esto lo manifestó el propio navegante. En 9, 10 y 11 contemplamos que los objetos concretos facilitaban el intercambio de ideas; pero hubo información de referentes abstractos. ¿Cómo hablar de autoridad, respeto, liderazgo o leyes? Hemos dicho que en esos momentos privaron mucho las ideas del Viejo Mundo, que hubo algo de transferencia en el momento de la comprensión. Veamos la cita 20:

(20) Y le dixe otra vez como ayer que Vuestras Altezas mandavan y señoreavan todo lo mejor del mundo, y que no avía tan grandes príncipes, y le mostré las banderas reales y las otras de la cruz, de que él tuvo en mucho, "y qué grandes señores serían Vuestras altezas", dezía él contra sus consejeros, "pues de tal lexos y del çielo me avían enviado hasta aquí sin miedo". Y otras muchas cosas se pasaron que yo no entendía, salvo que "bien vía que todo tenía a grande maravilla". (Colón, 1986 [1492], p. 132)

Y ahora preguntemos: qué pudieron entender los indígenas sobre las banderas y la cruz. Qué pudieron entender de lo que decían los europeos si en verdad estaban empeñados en creer que la visita había caído del cielo. En la última oración de 20, Colón dice algo interesante: "y otras muchas cosas se pasaron que yo no entendía". En efecto, hablaban los indígenas, informaban, relataban, reflexionaban, pero como no tenían lengua común, se perdió mucho de lo que dijeron. A medida que las necesidades de los exploradores se hacían más complejas, crecían las restricciones de las señas. En efecto, los documentos, de igual modo, testimonian que las señas a veces no satisfacían a Colón. En 21 se queja porque no comprende todo lo que quisiera. 
(21) Y él y su ayo y consejeros llevan grande pena porque no me entendían, ni yo a ellos. Con todo, le cognoscí que me dixo que si me compliese algo de aquí, que toda la isla estava a mi mandar. (Colón, 1986 [1492], p. 130)

El navegante no tiene certeza, pero alguna idea se hace de lo que le dicen. Esas ideas las delinea con su mundo y su conocimiento a partir de los gestos. El Almirante no procesa toda la información deseada. Se lamenta porque no entiende, aunque inmediatamente agrega que eso no le impide comprender lo que su interlocutor expresa. Pero en otras ocasiones, confirmamos que la insatisfacción lo embargaba, que se frustraba ante la reducida comunicación. En varias oportunidades expone con mayor claridad su consternación:

(22) Trabajé que fuesen allá. Y después vide que no entendían en la idea. (Colón, 1986 [1492], p. 61)

(23) Aunque en pocos días no se puede saber de una tierra mucho, así por la dificultad de la lengua, que no entendía el almirante. (Colón, 1986 [1492], p. 171)

(24) Recibieron ambas las partes gran pena porque no se entendían, ellos para preguntar a los otros de nuestra patria, y los nuestros para saber de la suya. (Colón, 1986 [1498], p. 231)

No entienden las informaciones más complejas, más estructuradas. Las señas ayudan en mucho, pero muchos detalles se pierden y muchos hechos se confunden. Por ejemplo, Humboldt (1941 [1811/1814]) cuenta que la denominación "Guaiquerí"2 proviene de una confusión. Unos españoles les preguntaron a unos pescadores nativos cómo se llamaban y ellos creyeron que averiguaban por el tipo de arpón que utilizaban para pescar y respondieron guaike. La reproducción errónea y la posterior propagación impusieron el gentilicio que ha llegado hasta hoy. Ahora bien, si el desliz sobrevino debido al poco dominio de la lengua oral, imaginémonos qué desencuentros no surgieron de la mala interpretación de las señas. Pero no importa, porque se trata de datos menudos, insignificantes, que no dejaron secuelas. Sin embargo, no ocurrió así siempre, las confusiones pudieron ser perniciosas como se estimará en las líneas que siguen.

\section{Las señas y las confusiones}

Cuando dos mundos, dos culturas con muchas diferencias se encuentran también hay espacio para las confusiones, para los equívocos. ¿Cómo evitar que, a partir de la gestualidad, cada quien no interpretara lo que quisiera? ¿Cómo impedir que cada quien entendiera lo que su mundo e intereses impusieran? Martinell-Gifre recrea la situación:

\footnotetext{
Los españoles entienden informaciones parecidas de los gestos de los indios: que tienen reyes, que están en guerra con sus vecinos, que son gente de paz. Es evidente, que cada cual interpretaba las señales según su deseo. Se cuenta el caso de unos españoles que viendo al indio señalar hacia occidente, suponían que señalaba la existencia de oro. Viendo al indio señalar hacia el sur imitando el sonido del agua que se estrella, creían ver y escuchar el martilleo de los que trabajaban el oro. (1992, p. 133)
}

¿Cómo inhibir la interpretación de estos hombres? ¿Cómo impedir que su mundo, su condición de vida, sus expectativas, necesidades y sueños no se interpusiera, no se activara en la interacción gestual? Imposible sortearlo, lo determina la condición humana. Muchos interpretaron lo que su mundo les permitió, a veces acertaron, otras no. Nuevamente correspondió al Almirante dejar constancia de ello. El 27 de noviembre en su Diario se lamentaba porque no conocía la lengua autóctona, lo que ocasionalmente generaba equívocos: 
Por consiguiente, presuponemos que hubo muchísimas confusiones, la mayoría de las cuales no dejó rastro, pero hubo otras que sí. Por intermedio de Colón conocemos un incidente de esta clase que no se logró mediante señas manuales. En la Carta-Relación de su tercer viaje ordenó tocar un tambor como señal de bienvenida, pero los nativos interpretaron los sonidos del instrumento de otro modo. Veamos cuál:

(26) al cabo de buen rato se allegaron más que hasta entonces no avían; y yo deseaba mucho aver lengua, y no tenía ya cosa que me pareciese que era de mostrarles para que viniesen, salvo que hize sobir un tamborín en el castillo de popa, que tañesen e unos mançebos que dançasen, creyendo que se allegarían a ver la fiesta. Y luego vieron tañer y dançar, todos dexaron los remos y echaron mano a los arcos y los encordaron, y enbraço cada uno su tablachina y començaron a tirarnos flechas. (Colón, 1986 [1498], p. 228)

Para los nativos el toque del tambor no simbolizó invitación ni bienvenida a una fiesta como lo proyectó Colón; paradójicamente, significó la inevitabilidad de un enfrentamiento bélico. Conque se consiguió el efecto contrario: no logró amistad, sino enemistad; no consiguió confianza, sino desconfianza. Confirmado: se encuentran frente a frente departiendo el mismo espacio dos maneras de organizar el mundo; mientras hacen ajustes, mientras las predicciones sean las equivocadas, habrá problemas. Con toda razón, Duranti afirma que los interlocutores "deben poseer formas de realizar predicciones en su vida cotidiana, ya que, de lo contrario, vivirán en un estado de permanente caos e incertidumbre que no les garantizará su bienestar" (2000, p. 78). Probablemente por desconocimiento alguien hizo la predicción equivocada el 3 de diciembre de 1492, lo que desencadenó otro desencuentro.

(27) Mandó dar al indio de comer y dióle pedaços de paño verde y colorado y cuentezuelas de vidrio, a qu'ellos son mu affiçionados; y tornóle a enbiar a tierra y díxole que truxese oro si lo avía, lo cual creía por algunas cositas suyas qu'él traía. En llegando la barca a tierra, estavan detrás los árboles bien cincuenta y cinco hombres [...]. Descendió el indio en tierra y hizo que los otros dexasen sus arcos y flechas y un pedaço de palo que que es como un *** muy pesado que traen en lugar de espada; los cuales después se llegaron a la barca, y la gente de la barca salió a tierra y començaronles a comprar los arcos y flechas y las otras armas [...]. Vendidos dos arcos no quisieron dar más, antes se aparejaron de arremeter a los cristianos y prendellos. Fueron corriendo a tomar sus arcos y flechas donde los tenían apartados y tornaron con cuerdas en las manos para diz que atar los cristianos. Viéndolos venir corriendo a ellos, estando los cristianos apercibidos [...], arremetieron los cristianos a ellos, y dieron a un indio una gran cuchillada en las nalgas, y a otro por los pechos hicieron con una saetada; <a> lo cual, visto que podían ganar poco, aunque no eran los cristianos sino siete y ellos cincuenta y tanto, dieron a huir que no quedó ninguno, dexando unos aquí las flechas y otros allí los arcos. (Colón, 1986 [1492], p. 168 y s.).

Primero hubo temor, recelo; luego acercamiento, intercambiaron objetos, hubo rescate, finalmente, llegó la ruptura. Se rompió la paz y devino la refriega. Nunca sabremos cuál fue el móvil que desató la violencia, pero sí sabemos que no pudo generarla el lenguaje verbal. Se debió de malinterpretar algún gesto. Hoy sabemos que no ocurrió lo esperado. Otras situaciones nada inocuas debieron fraguarse, aunque no tengamos referencias de ellas, situaciones que produjeron ruptura de relaciones y otras indeseables consecuencias.

La falta de comprensión se debe a que están frente a frente dos culturas diferentes, culturas que nunca antes se han visto, dos culturas que no pueden compartir sus gestos porque los gestos están muy lejos de constituir un sistema determinado por una motivación natural. Algunos gestos, símbolos y señas como la lengua oral difieren en distintas culturas porque también son un acervo social y cultural (LeBaron y Streeck, 2000). Las predicciones que se hicieron a partir de un gesto fueron incorrectas. Un gesto que genera aprobación en una cultura, produce desazón en otra porque el "código cinético, compuesto por miradas, muecas, expresiones del rostro, posturas, acompaña y completa el sentido de las palabras en base a una serie de normas y convenciones compartidas y está íntimamente relacionado con 
la cultura de cada país" (Brandimonte, 2005, p. 203 y s.). Los gestos como cualquier signo, a veces, no poseen denotación universal, cada cultura ha estructurado su propio sistema, en este sentido, también son arbitrarios como el signo lingüístico y también son productos de alguna convención (McNeill, 1998); por ello, tienen valor estable dentro de cada cultura, pero no fuera de ella. Si bien hay señas universales como mover la cabeza para afirmar o negar, hay otras que son locales. Por ejemplo, las culturas occidentales suelen representar el signo $O K$ (acuerdo, aprobación, etc.) con la mano cerrada, haciendo un puño, colocando el dedo pulgar apuntando hacia arriba, pero esta señal en ciertos países denota la 'homosexualidad' y en otros alude a algo "nulo, inválido, rechazable" (Briz, Albelda y Fernández, 2008, p. 160). Específicamente, sobre el encuentro de dos mundos Martinell-Gifre lo había explicado: los "signos no tienen valor universal; lo tienen estable, sí, y bastante duradero, pero sólo para los miembros de una misma cultura, y esa no es precisamente la circunstancia que se dio" (1992, p. 132). Los interlocutores del escenario que nos ocupa estaban muy lejos desde el punto de vista cultural; elementalmente, la circunstancia forjada fue la de dos culturas paralelas, la de dos lenguas paralelas. Consiguientemente, llegó un momento en que las señas españolas nada expresaban, quizás a cada nativo nuevo que encontraba le manifestaban más las señas de otros naturales. Por otro lado, estos conocían mucho mejor el mundo por el que debían navegar las carabelas. En este confluir de eventos, Colón creyó mejor presentarse mediante intérpretes. Sobre ellos hablaremos en los próximos folios.

\section{Los intérpretes}

Se planificó al detalle el primer viaje colombino. Se dispusieron las naos. Se calcularon las provisiones y, cómo no, se seleccionó con cuidado la tripulación. El día de la partida no faltaron hombres bizarros que leyeran el mar, el viento y las estrellas, pero tampoco estuvieron ausentes quienes ejercieran ciertos oficios específicos que cubrirían necesidades elementales: cocinero, físico, cirujano, boticario, sastre, tonelero y platero (Valera, 1986). Además, viajaban a tierras extrañas y lejanas. Buscaban el mundo oriental y, con razón, presuponían que otras lenguas ajenas a la castellana se oirían, por lo que también embarcaron dos intérpretes.

Requerían intérpretes porque ellos en ese ayer, al igual que hoy, comunican mundos lingüísticos y culturales diferentes. El intérprete explica a alguien, en lengua que entiende, la información que otro dijo en una lengua que ese alguien no conoce. Se supone que el intermediario cumple su trabajo porque conoce ambas lenguas y culturas (Taft, 1981).

A quienes concibieron el viaje les pareció que Rodrigo de Jerez y Luis Torres podían ejercer el oficio. El primero había estado en contacto con varias lenguas africanas, puesto que había vivido períodos prolongados en África. El segundo era un judío converso, quien dominaba varias lenguas orientales, además del árabe y del hebreo (Varela, 1986). En su caso, debían unir a Europa y a Asia; sin embargo, eso no ocurrió. No atracaron en Asia. Los conocimientos lingüísticos de los intérpretes extranjeros no sirvieron en aquel territorio. No desentrañaron los sonidos oídos. Cuando Cristóbal Colón reparó en que ni Torres ni Rodrigo de Jerez realizarían su trabajo, decidió que algunos nativos los suplirían. A partir de entonces los nativos hicieron de intérpretes, a veces solos, otras en compañía de algún europeo, a veces a través de la oralidad; pero otras tantas con señas, las cuales siempre utilizaron cuando debieron interpretar frente a los hispánicos. Dicho de otro modo: los nativos interpretaron por medio de señas.

Colón prontamente cayó en cuenta que mucho del éxito de su viaje dependía del conocimiento y de la habilidad de estos seres. Al instante de tenerlos a su disposición les 
asignó tareas interpretativas. Los envió a que mediaran ante los miembros de los pequeños poblados con los que se tropezaban:

(28) Enbió ocho hombres bien armados y con ellos dos indios de los que traía para que viesen aquellos pueblos de la tierra dentro y por aver lengua. (1986 [1492], p. 109)

(29) Y enbío algunas personas de la nao con ella [una india muy moça y hermosa], y tres de los indios que llevava consigo, porque hablasen con aquella gente. (1986 [1492], p. 122)

Asimismo, explica cómo efectuaban sus deberes. Los mediadores presentaban a los cristianos. Hablaban de su forma de vida (30), resaltaban su bondadoso carácter $(30,31)$, su extraordinario origen y el objetivo de su viaje (32).

(30) El indio que con ellos iva les notificó la manera de bibir de los cristianos y cómo eran buena gente. (Colón, 1986 [1492], p. 88)

(31) Y como los vieron, hombre y mugeres dan de huir; asegurólos el indio que llevaba consigo de los que traía, diciendo que no oviesen miedo, que gente buena era. (1 Colón, 986 [1492], p. 111)

(32) Uno de los indios que traía el almirante habló con él, y le dixo cómo venían los cristianos del çielo, y que andava en busca de oro y que quería ir a la isla de Baneque, y él respondió que bien era y que en la dicha isla avía mucho oro; el cual amostró al alguacil del Almirante. (Colón, 1986 [1492], p. 127)

Y aunque a veces los pobladores huían, en otras ocasiones los intérpretes lograron concretar con éxito sus funciones. Controlaban el temor y atenuaban el recelo del otro. En seguida, los nativos se aproximaban a los extranjeros y finalmente comenzaban los intercambios.

(33) El indio que llevavan los cristianos corrió tras de ellos (indios) dando bozes, diziendo que no oviesen miedo, que los cristianos no eran Caniba, mas antes eran del cielo y que daban muchas cosas hermosas a todos los que hallavan. Tanto les imprimió lo que dezía, que se aseguraron y vinieron juntos d'ellos más de dos mill, y todos venían a los cristianos y les ponían las manos sobre <la > cabeça, que era señal de gran reverencia y amistad. (Colón, 1986 [1492], p. 123)

(34) Y después de comer tornó a enviar a tierra uno de los indios que llevava, el cual desde lexos le dio bozes diciendo que no oviesen miedo porque eran buena gente y no hazían mal a nadie [...] y echase a nadar el indio y fue a tierra, y dos de los de allí lo tomaron de braços y lleváronlo a una casa donde se informaron d'él; y como fueron çiertos que no se les avía de hazer mal, se aseguraron y vinieron luego a los navíos más de diez y seis almadías o canoas con algodón hilado y otras cosillas suyas. (Colón, 1986 [1492], p. 83)

También procuró el virrey que los mediadores extranjeros realizaran su cometido. Y ya percatado de la dificultad de la tarea, organizaba equipos de trabajo. Disponía comisiones integradas tanto por indios como por los políglotas que había traído.

(35) Determinó el Almirante de llegar a aquel río enbíar un presente al rey de la tierra y enviarle la carta de los Reyes, y para ella tenía un marinero, que avía andado en Guinea en lo mismo, y ciertos indios de Guanahaní que querían ir con él con que después los tornasen a su tierra. (Colón, 1986 [1492], p. 82)

(36) Acordó el Almirante enbiar dos hombres españoles: el uno se llamava Rodrigo de Xerez, que bivía en Ayamonte, y el otro era un Luis de Torres, que avía bivido con el Adelantado de Murcia y avía sido judío, y sabía diz que ebraico y caldeo y aun algo de arávigo; y con estos enbió dos indios: uno de los que consigo traía de Guanahaní y el otro de aquellas casas que en el río estavan poblados. (Colón, 1986 [1492], p. 85)

Enfrentar aquella situación no fue fácil. La evolución había llevado al hombre al lenguaje articulado, en tanto el sistema gestual lo usaban unos pocos, marginados en aquella época. Ninguna de las culturas estaba preparada para el encuentro de dos mundos ni para la comunicación sin oralidad. De pronto, se hizo necesario el lenguaje gestual y en el camino lo desarrollaron. Con limitaciones y mucha improvisación lograron ciertos diálogos y Colón, de aquellas señas, extrajo más que trocitos de oro. 


\section{Intérpretes y algo más}

En esa época fueron determinantes los intérpretes. Cuando dos culturas desconocidas se ven por primera vez, no extraña que surja desconfianza y que la una quiera protegerse de la otra. En esos momentos difíciles, los intérpretes asumen delicadas responsabilidades. Así que, eventualmente, la vida de los españoles recayó en las habilidades interpretativas de los nativos. Por ejemplo, una vez se encontraron americanos y europeos. Un líder nativo intervino vehementemente:

(37) Ayuntáronse muchos indios y vinieron a las barcas, donde ya se avía el Almirante recogido con su gente toda. Uno d'ellos se adelantó en el río junto con la popa de la barca y hizo grande plática que el Almirante no entendía, salvo que los otros indios de cuando en cuando alçavan las manos al çielo y daban una grande boz. Pensaba el Almirante que lo aseguravan y que les plazía de su venida, pero vido al indio que consigo traía demudarse la cara y amarillo como la çera, y temblaba mucho, diciendo por señas que el Almirante se fuese fuera del río, que los querían matar, y llegóse a un cristiano que tenía ballesta armada y mostróla a los indios; y entendió el Almirante que les dezía que los matarían todos, porque aquella ballesta tirava lexos y matava, también tomó una espada y la sacó de la vaina mostrándosela, diciendo lo mismo. Lo cual oído por ellos, dieron todos a huir. (Colón, 1986 [1492], p. 112)

Gracias a la labor del mediador, se evitó un conflicto. Presuponemos que por el tono y los gestos los europeos concluyeron que el otro rechazaba su presencia; pero el paso entre la conjetura y la certeza lo dio el intérprete, y si bien verbalizó, también esgrimió el lenguaje no verbal: mostró la ballesta y la espada. El lengua no solo comprendió lo que decía el nativo desconocido, sino que decidió hablar en representación de los españoles y amenazó al grupo enemigo, en tanto simultáneamente le indicaba a Colón que debían retirarse. En tal sentido, vale señalar que la tarea de estos hombres no acaba en la interpretación ni en la de protectores como acabamos de ver. En las líneas siguientes, se apreciará que ellos también operaron como guías, sabían que había después de la siguiente isla, cómo eran los pobladores $(38,42)$; geógrafos, podían señalar las direcciones, el número de ríos, islas, montañas y sus dimensiones, así como las distancias $(38,40,41,42)$; geólogos, sabían en qué lugar localizar los minerales preciosos $(43,44)$, y etnógrafos, describían las costumbres de los hombres de estos predios $(45,46,47)$ :

(38) Y al Leste de la parte del Sueste y Sur, adonde entendí d'estos hombres que yo traigo que era la población y el rey d'ella. (Colón, 1986 [1492], p. 73)

(39) Y llegamos [...] a la punta d'él Norte y otro entre él y la isla grande, la cual anombraron estos hombres de San Salvador que yo traigo la isla Saomete, a la cual puse nombre la Isabela. (Colón, 1986 [1492], p. 71)

(40) Y aquellos hombres que yo tenía toma[n]do me dezían por señas que eran tantas y tantas que no avía número y anombraron por su nombre más de ciento. (Colón, 1986 [1492], p. 63)

(41) [Toda esta tierra] llena es de muchas agua, según pudo entender de indios que consigo lleva, que tomó en la isla Guanahaní, los cuales le dizen por señas que ay diez ríos grandes y que con sus canoas no la pueden cercar en XX días. (Colón, 1986 [1492], p. 80)

(42) Començó a ver al poner del sol, adonde se amostravan dos grandíssimas montañas, y pareçía que se apartava la tierra de Cuba con aquella de Bofío; y esto dezían los indios que consigo llevaban por señas. (Colón, 1986 [1492], p. 93)

(43) Porque los indios que traía le dixeron ayer martes que avría tres jornadas desde el río de Mares hasta la isla de Baneque, que se debe entender jornadas de sus almadías, que pueden andar 7 leguas. (Colón, 1986 [1492], p. 94)

(44) Aquí en el cabo no es la población salvo allá más dentro, adonde dizen estos hombres que yo traigo qu'esta el rey y que trae mucho oro. (Colón, 1986 [1492], p. 72) 
(45) Mucho affirmavan los indios que traía que se llamava Baveque, adonde, según dizen por señas, que la gente d'ella coge el oro con candela e noche en la playa. (Colón, 1986 [1492], p. 90)

(46) Todos estos hombres que yo traigo de la de San salvador hacen señas que ay muy mucho oro, y que lo traen en los braços en manilla y a las piernas y a las orejas y al nariz y al pescueço. (Colón, 1986 [1492], p. 65)

(47) Dezíanle los indios que avía tomado [...] que la gente de allí eran cañíbales, y allí avía o nascía el oro, y las perlas de la parte del norte de Paria, la vía del poniente, se pescavan y avían avido las que al Almirante dieron. (Colón, 1986 [1498], p. 262)

Pero las circunstancias que rodean a estos imprevistos intérpretes, en modo alguno, fue la ideal. Tres argumentos así lo confirman: (i) su conocimiento era parcial. Aunque conocían el mundo americano, a veces desconocían la lengua americana que debían interpretar; además, ignoraban por completo la lengua y el mundo de los recién llegados. (ii) Intercedían ante viejos enemigos o, simplemente, no-amigos. E (iii) interpretaban bajo coacción.

\section{La formación de los intérpretes}

Ni escogieron interpretar ni se formaron para ello. Les correspondió asumir este rol por circunstancias fortuitas. Abordaron las naves y luego no los dejaron desembarcar: los raptaron. Hicieron de intérpretes porque fueron más confiados, más fácil de atrapar, suficientemente extrovertidos, tenían habilidades para ese rol, etc. Emboscados, se vieron obligados a llevar a cabo la tarea y, adicionalmente, Colón se percató de que sin ellos no sería virrey. No tenían escapatoria. Ante tal desarreglo, el Almirante ideó capturar nativos y llevarlos a España para que, inmersos en la lengua castellana, la aprendieran prontamente. Como lo comenta Las Casas en un fragmento (48) del resumen que hizo del Diario, a Colón le pareció "que fuera bien tomar algunas personas".

(48) Dixo [...] que le avía parecido que fuera bien tomar algunas personas de las de aquel río para llevar a los reyes porque aprendieran nuestra lengua, para saber lo que ay en la tierra, y porque volviendo sean lenguas de los cristianos. (Colón, 1986 [1492], p. 91)

Y es verdad. Juzgó tan viable su propuesta que así lo hizo. Desde el primer momento tomó unos seis o siete indígenas de los que se subieron a las carabelas (49 y 50). Y, además, los ofreció a los reyes (49).

(49) Yo placiendo a Nuestro Señor levaré de aquí al tiempo de mi partida seis a Vuestra altezas para que deprendan fablar. (Colón, 1986 [1492], p. 60)

(50) Como verán Vuestras Altezas de siete que yo hize tomar para le llevar y deprender nuestra fabla y bolvellos. (Colón, 1986 [1492], p. 63)

Conduciría estos hombres a España, luego de unos meses los regresaría. Su pasantía por tierras europeas les proveería del conocimiento lingüístico y cultural necesario. Y llevó a cabo su plan. En el segundo viaje colombino en puerto de Cádiz embarcaron cinco indios lenguas, luego de varios meses en España y habiendo sido bautizados. Oficialmente les encargaron interpretar el evangelio a sus convecinos. Cabe señalar que entre ellos se encontraba Diego Colón, quien posteriormente fungiría como uno de los principales intérpretes del Almirante (Alonso-Araguás, 2005).

Como hemos dicho, Colón se dio cuenta de que sin intérpretes peligraba el objetivo de su misión. Y pensó que los castellanos también debían aprender las lenguas autóctonas de aquellas tierras. Del mismo modo, juzgaba que la tarea debía empezar por casa, por lo que se comprometió buscar los medios para que su gente aprendiera la nueva lengua:

(51) Y faré enseñar esta lengua a personas de mi casa. (Colón, 1986 [1492], p. 107) 
Pero no conforme con ello, igualmente, ideó que la mujer nativa podía asumir responsabilidades en el rol formación de intérprete. Presuponemos que el Almirante avistaba que, en un mundo exento de educación formal, la mujer debido a sus tradicional responsabilidad hogareña (madre y de ama de casa) podría colaborar significativamente en la enseñanza de la lengua.

(52) Y también estas mugeres mucho enseñarán a los nuestros su lengua. (Colón, 1986 [1492], p. 92)

En 53 detalla algo más su plan formativo. A todas luces resulta hoy de inmersión y acultural. Llevará a España a los caníbales sin distinción de edad ni sexo, los aislará unos con otros, los destinará a hacer vida de servicio europeo y de esta manera para comunicarse deberán usar el castellano y así lo aprenderán. Se les bautizará y perderán su hábito antropófago. Posteriormente, los retornará para que siendo ciudadanos nuevos, con nueva policía, multipliquen la cultura, la religión y la lengua de los blancos:

\begin{abstract}
(53) Item diréis a sus altesas que, a cabsa que acá non ay lengua por medio de la cual a esta gente se pueda dar a entender nuestra santa fe, como sus Altesas desean [...] se enbía de presente con estos navíos así de los caníbales, ombres e mujeres e niños e niñas, los cuales Sus Altesas pueden mandar poner en poder de personas con quien puedan mejorar aprender la lengua, exercitándoles en cosas de servicio, e poco a poco mandando poner en ellos algún más cuidado que en otros esclavos, para que deprendan unos apartados de otros, que non se fablen ni se vean sino muy tarde, que más prefetamente deprenderán allá que non acá, e serán mucho mejores intérpretes, como quier que acá non se dexará de faser lo que se pueda [...] parecerá acá que tomar d'ellos e d'ellas e enviarlos allá en Castilla no sería sino bien, porque quitarse ían una ves de aquella inhumana costumbre que tienen de omer ombres, e allá en Castilla, entendiendo la lengua, muy más presto rescibirán el bautismo e farán el provecho de sus almas. (1986 [1493-1496], p. 207 y s.)
\end{abstract}

Hoy se reconoce y queda explícito que la decisión colombina de apoderarse de los nativos se trató de un secuestro. Si bien pudo haber indígenas que navegaron plácidamente o que decidieran embarcarse, también es cierto que no se les consultó la medida. De hecho, hay evidencia de que Colón los retuvo a la fuerza. Veamos el fragmento 54:

(54) No quiso ir a la isleta que llamó Isabela [...] por dos razones: la una porque vido dos islas al Sur, las quería ver; la otra, porque los indios que traía, que avía tomado en Guanahaní, que llamó San Salvador, que estaba ocho leguas de aquella Isabela, no se le fuesen, de los cuales diz que tiene neçecidad y por traellos a Castilla. [cursiva agregada] (Colón, 1986 [1492], p. 98)

Lo dice todo la segunda parte de la cita 54. El Almirante escogió el trayecto que le permitía retener a los indígenas porque los necesitaba, precisaba traerlos a Castilla y podemos certificar con qué fin: sumergirlos en el mundo castellano para que lo aprehendieran. Los segmentos 48, 49, 50, 53 y 54 lo comprueban. Por otro lado, estos eventos generaron cierta inseguridad ante el rol que cumplían los intérpretes americanos: los europeos llegaron a desconfiar de la información que recibían.

\title{
9. Intérpretes y recelos
}

Transcurridos los días, los nativos desean regresar a casa, pero el Almirante los necesita y decidió retenerlos sin su autorización. Los improvisados intérpretes parecían ser prisioneros. En este orden de ideas, conviene recordar la cita 28. ¿Cuál sería la misión de los hombres armados, proteger a los intérpretes indígenas o evitar que huyeran? Ante esta circunstancia, ¿quién garantiza la veracidad de sus informaciones? ¿Los nativos reproducen fielmente el sentido? ¿Tergiversan la intención del discurso original? (cfr. Alonso-Araguás, 2005). Asegura 
Todorov (1982) que generalmente se desconfía de quien se expresa en una lengua que no se entiende. Si esto es así, la desconfianza que enraizó en ambos grupos fue significativa. En el caso que nos ocupa, el intérprete representa, en cierto modo, un enemigo, de manera que se pone en entre dicho la calidad de la interpretación o de la información.

(55) Dize el Almirante, que después que se partiese de allí, los tenía de llevar a sus casas, y que ya lo tenían por sospechosos, porque no lleva el camino de su casa, por lo cual dice que ni les creía lo que le dezían ni los entendía bien, ni ellos a él. (Colón, 1986 [1492], p. 117)

Colón no se atreve a creer todo lo que dicen los gestos (o lo que entiende): Estos intérpretes ¿dirán la verdad?, ¿por qué dicen aquello?, ¿por qué hacen énfasis en una información?

(56) Otras cosas le contavan los dichos indios, por señas, muy maravillosas; mas el Almirante no diz que las creía, sino que debían tener más astucia y mejor ingenio los de aquella isla Bohío. (Colón, 1986 [1492], p. 114)

(57) Porque estos que yo avía hecho tomar en la isla de San salvador me dezían que aí traían manillas de oro muy grandes a la piernas y a los braços. Yo bien creía que todo lo que dezían era burla para se furgir. (Colón, 1986 [1492], p. 64)

(58) Y yo de mañana quiero ir tanto avante que halle la población y vea o aya lengua con este rey que, según estos dan las señas, él señorea todas estas islas comarcanas, y va vestido y trae sobre sí mucho oro, aunque no doy mucha fe a sus dezires, así por no los entender yo bien como en cognoscer qu'ellos son tan pobres de oro que cualquiere poco qu'este rey traiga los pareçe a ellos mucho. (Colón, 1986 [1492], p. 72)

(59) Toda esta gente que hasta oy a hallado diz que tiene grandíssimo temor de los de Caniba o Canima [...] y dezían que no tenían sino un ojo y la cara de perro; y creía el Almirante que mentían, y sentía el Almirante que devían de ser del señorío del gran Can que los captibavan. (Colón, 1986 [1492], p. 104)

Desde las citas 55 a las 59 apreciamos el recelo colombino. Las circunstancias no eran fáciles para nadie. Vacilan entre creer o no. Los indígenas decían verdad o quizás decían lo que Colón quería oír. Si baja la guardia tendrían la oportunidad de escapar y dejarlo desamparado; consecuentemente, tendría que atrapar a otros intérpretes y volver a empezar en las relaciones y en el breve y superficial entrenamiento que presuponemos recibían. ¿Hay razones para que hubiera fidelidad en el discurso? El intérprete también pudo dudar. Si decía la verdad lo premiarían con el regreso a su comunidad, si decía una mentira, la gente poderosa que venía del cielo, podría castigarlo y nunca regresarlo con los suyos: pudo pensarlo. El aborigen estaba sometido, pero no le debía lealtad al español, acaso sí sentía temor, aprensión. Ambos grupos debieron padecer ese conjunto de dudas e incertidumbres.

\section{Y después de Colón}

Aunque el Almirante habló de unidad lingüística en estas tierras y aseguró que había una única lengua, luego se percató de que no era así. Además, sus sucesores lo comprobaron. La conquista y población demostraron que se trataba de un territorio multilingüe. Conque, la existencia de intérpretes que resolvieron por señas se mantuvo mucho tiempo. Casi un siglo después del primer viaje, aún los encontramos laborando en tierra americana:

(60) Comenzó a llamarlos por señales que les hacía y por algunos intérpretes que traía, que, aunque torpemente, entendían en alguna manera aquella lengua. [cursiva agregada] (Aguado, 1913 [1581], p. 137)

Aguado cuenta cómo los conquistadores alemanes e hispánicos incursionaron en Tierra Firme y cómo inmediatamente buscaron intérpretes. Como hemos aseverado arriba, las señas tuvieron utilidad en el primer contacto, servían para entregar un plato roto y recibir una 
perla, para pedir agua y recoger una totuma colmada de ella; pero no para eventos de mayor complejidad. Se hacía muy difícil explicar qué atajo tomar para llegar al destino, cuánto de belicoso era el carácter de la tribu próxima, cómo regresar al lugar de partida, dónde hallar el oro, etc. No había problemas cuando el intérprete manejaba la lengua en cuestión, pero otra cosa ocurría cuando la desconocía. Se apoyaban en la gestualidad. Actualizaban gesto y palabra para conseguir la información que buscaban (60).

Los exploradores sabían que en muchos casos su vida pendía de la lealtad y de la existencia del indio guía. Si una expedición perdía a su lengua, las posibilidades de éxito se reducían. ¿Dónde y de qué alimentarse? ¿Cómo zafarse del peligro? ¿Qué ruta seguir? Los aventureros se extraviaban en los montes americanos y quienes lograban subsistir quedaban maltrechos. En su Elegía lo recoge Juan de Castellanos:

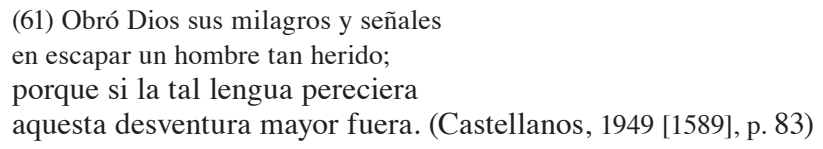

Si bien los hispanos desconfiaban del nativo, no tenían otras opciones que confiar su vida y el éxito de su empresa a quien no consideraban su amigo, alguien de quien recelaba. Por este motivo, se esforzaron en crear lazos, en agradar. Muchos de los intérpretes recibieron prebendas. Ese oficio significó ascenso social en el mundo que se impuso posteriormente. Con el paso del tiempo, los europeos también superaron este obstáculo porque contaron con compatriotas que empezaron a ensayar con alguna lengua nativa. Pedro Simón (1992 [1627]) recoge los casos de Gerónimo Ortal y de Francisco Martín, pero no ahondaremos en ese tema porque es harina de otro costal; sondearemos más bien en otra forma de comunicación no verbal: la ilustración.

\section{Las ilustraciones}

¿Cómo fueron las primeras vivencias del nativo europeo y cómo las expresaron? ¿Qué encontraron? Buena parte de todo era nuevo para el hombre occidental y este quiso contárselo a sus congéneres. Pluma y papel tomó y comenzó a escribir. La nueva realidad es diversa, cambiante, multiforme. La flora y la fauna se multiplican, presentan diversa fisonomía y color. Ya Colón lo refiere el 16 de octubre:

(62) Aquí son los peçes tan disformes de los neustros, qu'es una maravilla. Ay algunos hechos, como gallos, de las más finas colores del mundo, azules, amarillos, colorados y de todas colores y otros pintados de mil maneras, y las colores son tan finas, que no ay hombre que no se maraville y no tome gran descanso a verlos. (Colón, 1986 [1492], p. 68)

Lo nuevo y lo diverso conquistó al conquistador. "Y aun crece la novedad en cada paso de los que se dan" (Gumilla, 1945 [1745], p. 34). En cada nueva fruta no solo reposaba un nuevo sabor, en cada nueva mirada no solo afloraba un nuevo color o una nueva combinación cromática; en cada nueva sondeada no solo surgía una forma inédita; sino que además brotaban de todos los lugares, se distribuían por todos lados y en grado sumo. El célebre navegante florentino, Américo Vespucio, lo expresó en varias oportunidades desde sus primeros días en el virreinato colombino:

(63) Qué diremos de otros pájaros, que son tantos y de tantas clases y colores de plumaje que maravilla verlos. La tierra es amena y fructífera, llena de grandísimas selvas y bosques siempre verdes, que nunca pierden las hojas. Las frutas son tantas que son innumerables y completamente diferentes de las nuestras. (Vespucio, 1962 [1504], p. 51) 
Medio siglo después, los europeos aún se maravillan de la diversidad que reina en el Mundo ignoto. ¿Cómo explicar, enumerar, clasificar la "gran cantidad" de especies? No resaltamos la clase de nutriente a la que alude el cronista, remarcamos la cantidad y la diversidad. Pedro de Aguado reconoce la extraordinaria pluralidad, pero escasos sus recursos para describirla:

(64) Todos estos ríos son abundantísimos de muchos géneros y diversidades de peces chicos y grandes $\mathrm{y}$ de todas suertes y de muy diferentes formas y hechuras; y porque en este caso, si particularmente yo hubiese de tratar de todos los géneros y formas y efectos de los peces que en éstos ríos se crían, sería ponerme a lo que no puedo cumplir. [cursiva agregada] (Aguado, 1913 [1581], p. 247)

Pedro Simón más de media centuria después, explicita la colosal multiplicidad americana mediante el contraste: la ordenada realidad europea frente a la pluralidad americana:

(65) de los árboles, fuera el nogal, encina, roble y en algunas partes pinos, cedros y alisos, zarzas de moras, no hay otros de nuestro conocidos, con ser infinitos los que hay. [...] [Y] otras mil [cursiva agregada] hermosísimas flores, gayombas o retamas. (Simón, 1992 [1627], p. 34)

El fraile reconoce, de igual manera, que el mosaico de culturas, formas y de gamas supera la posibilidad de relatar. No describe a los nativos corianos porque nunca acabaría. En sus propias palabras, se trata de la siguiente infinitud: "de cuya naturaleza y costumbres no me alargaré mucho, porque sería nunca acabar las diferencias” (Simón, 1992 [1627], pp. 87 y s.). Confirma que todo es inédito para el europeo; de hecho, ahora se justifica la designación nominal: el Nuevo Mundo. Un Nuevo Mundo caracterizado por la heterogeneidad:

(66) Puede llamarse también Mundo Nuevo, porque en todas las demás cosas está lleno de novedades. Las aves son nuevas y peregrinas de las de nuestra Europa, puesto sólo el águila, gavilán, lechuza, tórtola, garza, murciélagos y algunas de cetrería son las mismas de las que conocíamos y las demás son nuevas, porque aun hasta las palomas, gorriones, vencejos, aviones y golondrinas, tienen mucha diferencia de las nuestras. De los animales, sólo el venado, tigres y osos, nutrias, leones, zorros son como los nuestros; lo demás es nuevo. [cursiva agregada] (Simón, 1992 [1627], p. 34)

Los viajeros observan una vegetación desconocida, una naturaleza totalmente distinta a la suya, una extraña realidad. Quien escribía comenzó a registrar el mundo americano: Sus características, organización y distribución por primera vez serían recogidas por el mundo grafológico y, por tanto, trasladadas a otras latitudes. Pero a medida que escribía, lo invadió la sensación de que no sería entendido. ¿Cómo relatar el multiforme laberinto que se plantaba ante sus ojos?, ¿cómo plasmarlo?, ¿cómo hacer llegar al distante hombre europeo una realidad de la que carecía de referente? ¿Cómo hacer comprensible lo que ni él, que lo había visto, lograba comprender? ¿Qué tipo de esfuerzo lingüístico demanda esta neo-realidad? Entonces, prefirió acompañar su escritura con pinturas. Con ello, captó en una imagen un momento de la historia de la humanidad. Sobre los bocetos realizados por el hombre blanco para que sus congéneres entendieran el mundo americano, hablaremos de inmediato.

\section{Y la ilustración se hizo}

Otros cronistas más tarde sugirieron que únicamente mediante la pintura podría describirse la naturaleza. Vespucio reconoció las restricciones de la lengua europea para escribir el mundo que más tarde llevaría su nombre. En la relación de su primer viaje, lo señaló:

(67) Dimos con una población de mucha gente y de pocas casas, porque no eran más de nueve, donde fuimos recibidos con tantas y tan bárbaras ceremonias, que no basta la pluma para describirlas. [cursiva agregada] (Vespucio, 1962 [1504], p. 50) 
A Gonzalo Fernández de Oviedo y Valdés cuando le correspondió relatar tuvo una impresión similar:

(68) Papagayos hay muchos, y de tantas maneras y diversidades, que sería muy larga cosa decirlo, y cosa más apropiada al pincel para darlo a entender, que no a la lengua. [cursiva agregada] (Oviedo y Valdés, 1852 [1526], p. 492).

Creemos que la diversidad lo apabulló y que deseó pintar porque unas páginas más adelante reitera:

(69) Es de manera que es dificultoso de escribir su forma, y para darse a entender sería necesario pintarse, para que por medio de la vista se comprehendiese lo que la lengua falta en esta parte. [cursiva agregada] (Oviedo y Valdés, 1852 [1526], p. 506).

En una epístola escrita en Coro el 6 de septiembre de 1535 por otro joven alemán, empleado de los Belzares, Titus Neukomm, dirigida a su familia, en dos ocasiones se actualiza la pintura como recurso que facilita la aprehensión de los detalles. 71 y 72 aluden directamente a la vestimenta de los caquetíos. ${ }^{3}$

(70) El hombre no se cubre más que, como dije, con una pequeña calabaza. Y todos andan desnudos como Dios los ha creado y como tú lo puedes contemplar sobre un papel dibujado que incluyo, para que lo puedas ver, y saber. [cursiva agregada] (Neukomm, 1962 [1535], p. 409)

(71) Los hombres ponen sobre sus cabezas sombreros hechos de plumas de papagayo, así como está dibujado en el papelito. [cursiva agregada] (Neukomm, 1962 [1535], p. 411)

Cey también repitió que los dibujos podían ayudar a presentar a Europa el heterogéneo mundo:

(72) De los árboles, frutas, arbustos, de la tierra de dicha isla habría mucho que contar y ser buen dibujante, pero no siéndolo, sería mejor pasarlas ahora por alto. [cursiva agregada] (Cey, 1995 [1569?], p. 36)

Tardaría en desaparecer esa impresión. El jesuita José Gumilla en El Orinoco ilustrado y defendido aún refería que su escritura no podía abarcar la gama de peces americanos: "No es ponderable, ni cabe en la pluma expresar [cursiva agregada] la multitud de peces grandes que queda asegurada a la disposición de los indios" (Gumilla, 1945 [1745], p. 223 y s.). Unas páginas más adelante lo vuelve a repetir: "ni hallo término con que explicar su arquitectura [las cajas de guerra], por ser maniobra tan extravagante, que sin verla no se puede hacer cabal concepto de ella" (1945 [1745], p. 346). Cabe destacar que acompaña la descripción de la caja con una ilustración que aparece en la página siguiente a la explicación. En este mismo folio, también dibujó al "manatí o vaca marina a que se hace referencia en el capítulo XXI de la primera parte" (1945 [1745], p. 346).

Pese a que algunos de los cronistas dibujaron objetos, plantas y animales, entre los conocidos hasta hoy, fue Galeotto Cey, quien más se apoyó en esta técnica. Resueltamente, pasó de las palabras (hay que "ser buen dibujante") a los hechos. Llenó de ilustraciones su obra: más de cincuenta contamos en ella. Generalmente, remite a sus grabados con la frase "como veréis al margen". De inmediato, expondremos unas cuantas citas en las que Cey remite a las imágenes ${ }^{4}$ :

(73) La piña es una fruta de las más aromáticas y bellas que hay en todas las Indias y nace de una hierba como la alcachofa, aunque son las hojas más duras y aguzadas, y sale de ella el fruto como al alcachofa, verde antes de madurar y después amarilla, está formada exactamente como el fruto del pino, por eso lo llaman con ese nombre, y lo hay en gran cantidad. Más rápido nace en lugares áridos y secos que en otros, y en tierras cálidas se da de mayor tamaño [...]. Ordinariamente es como un melón común, las espinas 
de esa piña no se abren como las de los pinos, porque vienen pegadas con la concha verde, que cuando madura se pela con un cuchillo como un melón y es más delgada y más fácil de cortar. En la cima tiene ciertas hojas como un cogollo de alcachofa [...], y se forma como veréis al margen. [cursiva agregada] (Cey, 1995 [1569?], p. 41)

(74) Y hacen así ciertos panes [de sal] de la suerte que veréis al margen [cursiva agregada]; son del color de la tierra, veteados de blanco y negro, duros como piedras y lo hacen grandes y pequeños. (Cey, 1995 [1569?], p. 61)

(75) Para hacer pan, si es del duro de Yucatán, lo ponen en remojo de un día para otro y lo muelen en ciertas piedras, hechas como se ve en el margen [cursiva agregada], un poco curvas. (Cey, 1995 [1569?], p. 23)

(76) A las alhajas que llevan en las orejas, los españoles las llaman orejeras y están hechas como veréis al margen: de oro bajo de 6 y 7 quilates, vacías por dentro [...]. Las que ponen en la nariz las llaman caracolíes, hechas como veréis al margen. [cursiva agregada] (Cey, 1995 [1569?], p. 106)

(77) [En Quíbor] la sal se tiene en grandísima estima [...], y la hacen de una tierra superficial, salitrosa, cociéndola y colocándola con agua, hasta que se cuaja en ciertas vasijas, como veréis al margen. [cursiva agregada] (Cey, 1995 [1569?], p. 61)

(78) Elaboran, para llevar sus cargas y semillas, ciertas canastas pequeñas y grandes [...], hechos de cañas dobladas, tejidas a modo de paneras [...], estando llenas las puede llevar un indio o india a la espalda, colgadas de una cinta que se ponen en la cabeza, y está hecha de hilo de algodón, de cáñamo, de corteza o conchas de árbol [...], y están hechas como veréis al margen. [cursiva agregada] (Cey, 1995 [1569?], p. 114 y s.)

(79) Hacen ciertas sillas pequeñas y grandes [...]. Algunos están hechos de una sola pieza de leño, otras de madera y cañas, cubiertos con un cuero de ciervo, de tigre, de gato salvaje o de león. Son bajos, pero cómodos, de la suerte que veréis al margen. [cursiva agregada] (Cey, 1995 [1569?], p. 113)

(80) Estas canoas son las barcas de carga en que navegan los indios en todas aquellas partes, hechas todas de un trozo de tronco de árbol, que generalmente cortan de aquellos que llaman ceibas, por ser gruesos, tiernos, grandes y ligeros. [...]. Veréis su hechura al margen. [cursiva agregada] (Cey, 1995 [1569?], p. 84)

(81) Duermen estos indios en ciertas telas o redes, colgadas al aire, hechas de algodón, o de aquella cocuiza o cáñamo. Nosotros, los cristianos las usamos de tela de algodón, de 14 palmas de ancho y largas como un hombre, o poco menos, y son de una gran comodidad, para no dormir en tierra al amor de la humedad y de toda clase de animales. Es cosa muy pulcra y fresca para aquellos países, muy acomodada, colgándose al aire con dos cuerdas a los árboles, o en la casa a los maderos, alta de la tierra cuanto la persona quiera, como está dibujada al margen [cursiva agregada]. A Normandía llegan del Brasil muchas de las redes, pero donde yo estuve se hacen bellísimas y blancas, y en las puntas tienen ciertas lanzadas, hechas de la misma tela, en grandísima cantidad que parecen franjas, donde se introducen cordeles no muy gruesos, en cada uno de dichos lazos, de un brazo y medio de largo, y al fin de dichos cordeles se hace de todo un nudo, donde se mete la cuerda con que se cuelga. Llaman a estas telas o redes, hamacas. (Cey, 1995 [1569?], p. 107)

¿Qué mejor recurso lingüístico que los adjetivos para describir? Esta clase de palabras la reitera Cey, una y otra vez, en las citas: aromáticas, bellas, duras, aguzadas, verde, amarilla (73); veteados, blanco, negro, grandes y pequeños (74); curvas (75); superficial y salitrosa; (77); pequeñas, grandes, dobladas y tejidas (78); bajos y cómodos (79); gruesos, tiernos y ligeros (81); pulcra y fresca (81). Asimismo, repite estructuras comparativas sustentadas en el conocimiento occidental: como la alcachofa, como la de los pinos, como un melón (73); duros como piedras (74), a modo de paneras (78). Cuando no cuenta con estas fórmulas, enumera sus componentes y uso de los objetos en cuestión (76, 78, 79 y 80); su proceso de elaboración (77), etc. No obstante, Cey dudaba de sus habilidades verbales descriptivas, no las consideraba suficiente y dibujó y dibujó. 
Queda claro el uso que Galeotto Cey hizo de la imagen. Parece que no quería que nada impidiera que su lector comprendiera el mundo lejano. Describe el objeto con palabras, los compara con otros conocidos en Europa; pero se apoya en la pintura. Con la pintura se logra mejor la comunicación, recordemos que el signo lingüístico, que es el elemento mínimo constitutivo de la comunicación, se logra con la unión del significante y el significado. A partir del dibujo el lector occidental podía construir la imagen psíquica (Saussure, 1967 [1916]) porque cuenta con el significante y el significado.

Este tipo de tareas produce notables ventajas culturales hasta hoy: no solo se sabe qué usaban y, con ello, conocemos con mayor precisión esas agrupaciones, sino que además, resguarda sus formas del olvido. Por otro lado, tanto el europeo de ayer como el hombre actual, incluso, el americano, comprende mejor el mundo tropezado por Colón. En 73 apreciamos la forma de la piña; vemos la necesidad de la sal y cómo era su presentación en 74; con 75 aceptamos que el empleo de piedras como morteros lo heredamos de aquellos tiempos; el uso de accesorios que complementan la apariencia física de los aborígenes por compromiso étnico, por simbología o por mero capricho se aprecia en 76; 77 testimonia la elaboración de vasijas de barro para diversos fines; observamos en 78 otro tipo de recipiente, ahora hecho con material vegetal; la pintura al margen de la cita 79 ofrece al Viejo Mundo un nuevo tipo de mueble; el transporte de los nativos lo admiramos en la ilustración que acompaña a 80 y, en la anexa a 81, distinguimos las redes que usaban para dormir.

Los hablantes del castellano sentían la necesidad de informar, de comunicar a aquellos que nunca cruzarían el Atlántico el modo de vida de la otra orilla. Y el castellano, lengua hecha hasta entonces para el mundo europeo, no podía satisfacer por completo esas neo-necesidades. En esta situación, bueno fue dibujar. Los cronistas se quedan sin palabras para trasmitir con exactitud lo que observan. Los abrumó la diversidad y sintieron que no había palabras para describirla, transmitirla y captarla. En el curso de los días debieron constatar que "una imagen vale más que mil palabras" y, por ello, dibujaron.

\section{Conclusión}

Cuando el hombre europeo con su experiencia, sus órdenes y sus esquemas a cuestas alcanzó esta orilla del Atlántico, debió de verse sorprendido, desconcertado ante la nueva realidad. Un panorama para el que se nos antoja nunca se preparó. Todo fue inesperado. Martinell-Gifre resume en cuatro palabras el caudal de sensaciones que presupone afloró: "estupefacción”, “desasosiego", "pasmo" [...] y “maravillamiento" (1992, p. 79). En estas circunstancias y sin una lengua común, nos preguntamos cómo estos seres entraron en contacto con los nativos. Y eso respondimos en las páginas precedentes. Apreciamos cómo los gestos, la lengua de señas se impusieron. Luego vimos a los intérpretes comprender más señas que lenguas, mientras ejercían su rol y, finalmente, discriminamos que el impacto del encuentro fue tal que incidió en la forma de comunicación intercontinental, los europeos que atravesaron el océano dibujaron para comunicarse en la distancia.

Hubo concierto para las informaciones básicas. Los europeos sin entender un ápice de las voces, discriminando señas, muchas veces acompañadas de objetos concretos comprendieron alguna información, otra la dedujeron del contexto situacional a medida que iban conociendo la nueva civilización. Los gestos (acompañados de sonidos inentendibles) fueron el primer gran instrumento de comunicación. Varias expresiones de cronistas acopiadas 
por Martinell-Gifre lo atestiguan: "señas", "gestos", "ademanes" [...] "visajes", "meneos" y "y demostraciones"; así como también: "pedir con señas y voces"; "hablar con palabras y señas", "preguntar por señas y palabras", "llamar con meneo y palabra", "responder en español y por señas" (1992, p. 131). Al igual que la autora pensamos que ambas culturas estaban afanadas por lograr el mutuo reconocimiento, y que les importaba más: "su acercamiento físico y la ausencia de agresividad" (1992, p. 128). Pero cuando la información requerida fue más compleja y no se contaba con un objeto que representara, el europeo debió confiar en sus instintos, debió predecir o simplemente reconocer que no entendía y que debía continuar la empresa sin manejar esos datos. Colón, aunque intentó atenuar su importancia, reconoció que el entendimiento no es absoluto. No tuvo manera de resolver la situación; por eso, acudió a los nativos para que fungieran como intérpretes como otra posibilidad.

A veces los nativos hicieron su trabajo, en otras no quisieron o no pudieron. Los europeos en oportunidades confiaron en ellos y en otras no, algunas veces tuvieron razón, otras no. Pero no hubo alternativas, el hombre nacido de este lado, leía mejor este mundo. Por otro lado, los hispánicos tuvieron que esperar el curso del tiempo para contar con intérpretes más confiables, como españoles o mestizos.

Pero los hombres de aquella época no solo quisieron y necesitaron comunicarse con los seres con quienes compartían el día a día, también quisieron informar al Viejo Mundo qué de inesperado veían, qué les llamaba la atención, ante qué se extrañaban, y escribieron epístolas familiares y crónicas. Pero muchas veces sintieron que ese Nuevo Mundo descrito únicamente con palabras nunca sería comunicado, las letras podían tergiversarlo; así que se decantaron por las imágenes y, entonces, pintaron, ilustraron, acompañaron sus escritos con dibujos.

Con estas tres herramientas queda demostrado que el hombre no tiene límites para comunicarse. Su inteligencia le permite crear inéditos sistemas comunicativos o reusar otros ya tradicionales. Si para comunicarse puede contar con el lenguaje verbal la actividad dialógica se dará sin inconvenientes lingüísticos, pero si no cuenta con la oralidad inventará señas, gestos, símbolos, representaciones, etc. De hecho, la sociedad actual así funciona, el llanto del niño indica que tiene hambre, las nubes negras que la lluvia se acerca y la luz roja del semáforo nos ordena detenernos. La comunicación se concreta porque respondemos ante estos hechos: le damos de comer al bebé, sacamos el paraguas y detenemos el vehículo. El lenguaje no verbal lo invade todo, pero pasa inadvertido porque lo practicamos de forma rutinaria. ¿Qué ocurrió en los días siguientes al 12 de octubre de 1492? Nada extraordinario. Solo quedó en evidencia nuestra capacidad innata para desarrollar cualquier tipo de lenguaje con tal de comunicarnos.

\section{Notas}

1. Este rol se realizó sin que los intérpretes conocieran la lengua del otro, por esta razón, el lenguaje articulado quedó fuera de los alcances de este estudio.

2. Guaiquerí: grupo indígena de Venezuela que residía en la zona nororiental, fundamentalmente, en la isla de Margarita.

3. Caquetío: pueblo amerindio que habitaba la región noroccidental de Venezuela, entre el estado Falcón y el lago de Maracaibo, pasando por los estados Yaracuy y Lara.

4. Todas las imágenes que constituyen el anexo de este artículo se extrajeron de Cey (1995 [1539/1553]). 


\section{Bibliografía}

Aguado, P. (1913 [1581]). Historia de Venezuela. Caracas: Academia Nacional de la Historia.

Alonso-Araguás, I. (2005). Intérpretes de Indias. La mediación lingüística y cultural en los viajes de exploración y conquista: Antillas, Caribe y Golfo de México (14921540). (Tesis doctoral no publicada, Universidad de Salamanca). http:/gredos.usal.es/ [Consulta 19 de septiembre de 2013].

Bécares, R. (2009, 19 de deciembre). Cuatro tomos del Quijote de 1819 y otros textos, en la cápsula del tiempo. Elmundo.es. http://www.elmundo.es/ [Consulta 19 de septiembre de 2013].

Benzoni, J. (1962). [1565]. Capítulos de Jerónimo Benzoni relativos a la Isla de Cubagua, Cumaná y los Belzares. (L.A. Uncein-Tamayo, tr.). Por J. Gabaldón-Márquez. Descubrimiento y conquista de Venezuela. (Vol. 2, 1-36). Caracas: Academia Nacional de la Historia.

Bienvenidos a la cápsula del tiempo: 'Estamos en 1834'. (2010, 27 de julio). Elmundo.es. http:// www.elmundo.es/ [Consulta 19 de septiembre de 2013].

Birdwhistell, R.L. (1952). Introduction to Kinesics: An Annonated System for Analysis of Body Motion and Gesture. Washington: Department of State - Foreign Service Institute.

Brandimonte, G. (2005). Competencia pragmática e interferencias culturales en la enseñanza del español a estudiantes italianos. Por A. Álvarez et ál. La competencia pragmática y la enseñanza del español como lengua extranjera. Actas del XVI Congreso Internacional de ASELE. Universidad de Oviedo. (196-208).

Briz, A., Albelda, M. y Fernández, M.J. (2008). Saber hablar. [A. Briz (Coord.)]. Colombia: Instituto Cervantes - Aguilar.

Castellanos, J. (1949 [1589]). Elegía de varones ilustres de Indias. Por B.C. Aribau. Biblioteca de autores españoles desde la formación del lenguaje hasta nuestros días. Madrid: ORBE.

Cey, G. (1995 [1539/1553]). Viaje y descripción de las Indias. 1539-1553. [Estudio preliminar, notase índices por J.R. Lovera]. (M. Vannini de Gerulewicz, tr.). Caracas: Fundación Banco Venezolano de Crédito.

Colón, C. (1986 [1492]). Diario del primer viaje. Por C. Valera (Ed.). Cristóbal Colón. Los cuatro viajes. Testamento. (39-199). Madrid: Alianza.

Colón, C. (1986 [1498]). Relación del tercer viaje. Por C. Valera (Ed.). Cristóbal Colón. Los cuatro viajes. Testamento. (221-273). Madrid: Alianza.

Colón, C. (1986 [1503]). Relación del cuarto viaje. Por C. Valera (Ed.). Cristóbal Colón. Los cuatro viajes. Testamento. (274-292). Madrid: Alianza.

Davis, F. (1969). La comunicación no verbal. Madrid: Alianza.

Duranti, A. (2000). Antropología lingüística. Madrid: Cambridge University Press.

Federmann, N. (1955 [1557]). Viajes a las Indias del Mar Océano. (N. Orfila, tr.). Buenos Aires: Nova. 
Fernández de Oviedo y Valdés, G. (1852 [1526]). Sumario de la natural historia de las Indias. Por E. De Vedia [Colección dirigida e ilustrada]. Autores españoles. Desde la formación del lenguaje hasta nuestros días. Historiadores primitivos de Indias. (471-515). Madrid: Imprenta y estereotipía de M. Rivadeneyra.

Gumilla, J. (1945). [1745]. El Orinoco ilustrado. [Constantino-Byle, S.J. (Introducción, notas y arreglos)]. Madrid: M. Aguilar.

Humboldt, A. (1941 [1811/1814]). Viaje a las regiones equinocciales del Nuevo Continente. Caracas: Ministerio de Educación Nacional.

Laitman, J.T. (1985). El origen del lenguaje articulado. Mundo Científico. 64 (6), 1182-1191.

Larsen-Freeman, D. y Long, M.H. (1994). Introducción al estudio de la adquisición de segundas lenguas. Madrid: Gredos.

Las Casas, Bartolomé de. (1962). [1566]. Capítulos de la "Historia de las Indias", Por Fray B. de Las Casas. (L.A. Uncein-Tamayo, tr.). Por J. Gabaldón-Márquez. Descubrimiento y conquista de Venezuela. (Vol. 1). Caracas: Academia Nacional de la Historia.

LeBaron, C. y Streeck, J. (2000). Gestures, knowledge and the world. Por D. Mc-Neill (Ed.). Language and gesture. (118-138). Cambridge: Cambridge University Press.

Llorens-Cerdà, F. y Capdeferro-Planas, N. (2011). Posibilidades de la plataforma Facebook para el aprendizaje colaborativo en línea. Revista de Universidad y Sociedad del Conocimiento. 8 (2), 31-45. http://www.raco.cat/ [Consulta 19 de septiembre de 2013].

Martínez-Díaz, P. (1997). La comunicación no verbal, una propuesta cinematográfica. Cuadernos Cervantes de la lengua española. 16, 50-53.

Martinell-Gifre, E. (1992). La comunicación entre españoles e indios. Madrid: MAPFRE.

McNeill, D. (1998). Speech and gesture integration. Por J. Jverson y S. Goldinmeador (Eds.). The Nature and Functions of Gesture in Children's Communication. (11-27). San Francisco: Jossey-Bans Pub - University of Chicago.

Neukomm, T. (1962 [1535]). Carta de un joven alemán: Titus Neukomm. (J. Friede, tr.). Por J. Gabaldón-Márquez. Descubrimiento y conquista de Venezuela. (Vol. 2, 403-412). Caracas: Academia Nacional de la Historia.

Phail-Fanger, E.M. (2009). Tiempo social y memoria en algunos trabajos de comunicación visual. Acta Sociológica. 49, 147-171. http://revistas.unam.mx/ [Consulta 19 de septiembre de 2013].

Rodríguez-Flores, J.G. (2002). SETI: Búsqueda de Inteligencia Extraterrestre. Astronomía digital. 4. http://www.astrored.org/ [Consulta 19 de septiembre de 2013].

Salmones-Castañeda, H.G. (2008). De regreso a los orígenes. [doc.]. www.filos.unam.mx/ [Consulta 19 de septiembre de 2013].

Saussure, F. (1967 [1916]). Curso de Lingüística General. Losada: Buenos Aires.

Simón, P. (1992 [1627]). Noticias historiales de Venezuela. (Vol. 1 y 2). Caracas. Biblioteca Ayacucho. 
Taft, R. (1981). The role and personality of the mediator. Por S. Bochner (Ed.). The Mediating Person: Bridges Between Cultures. (53-58). Boston: G.K. Hall and Co.

Todorov, T. (1982). La conquête del Amérique. La question del autre. París: Seuil.

Valera, C. (1986). Introducción. Por C. Valera (Ed.). Cristóbal Colón. Los cuatro viajes. Testamento. (7-38). Madrid: Alianza.

Vespucio, A. (1962 [1504]). La letrera de 4 de septiembre de 1504. Por J. Gabaldón-Márquez. Descubrimiento y conquista de Venezuela. (Vol. 1, 39-61). Caracas: Academia Nacional de la Historia. 
Anexo 1. Imágenes del cronista Galeotto Cey (1995 [1569?], pp. 23, 41, 61, 84, 106, 107 113, 114)

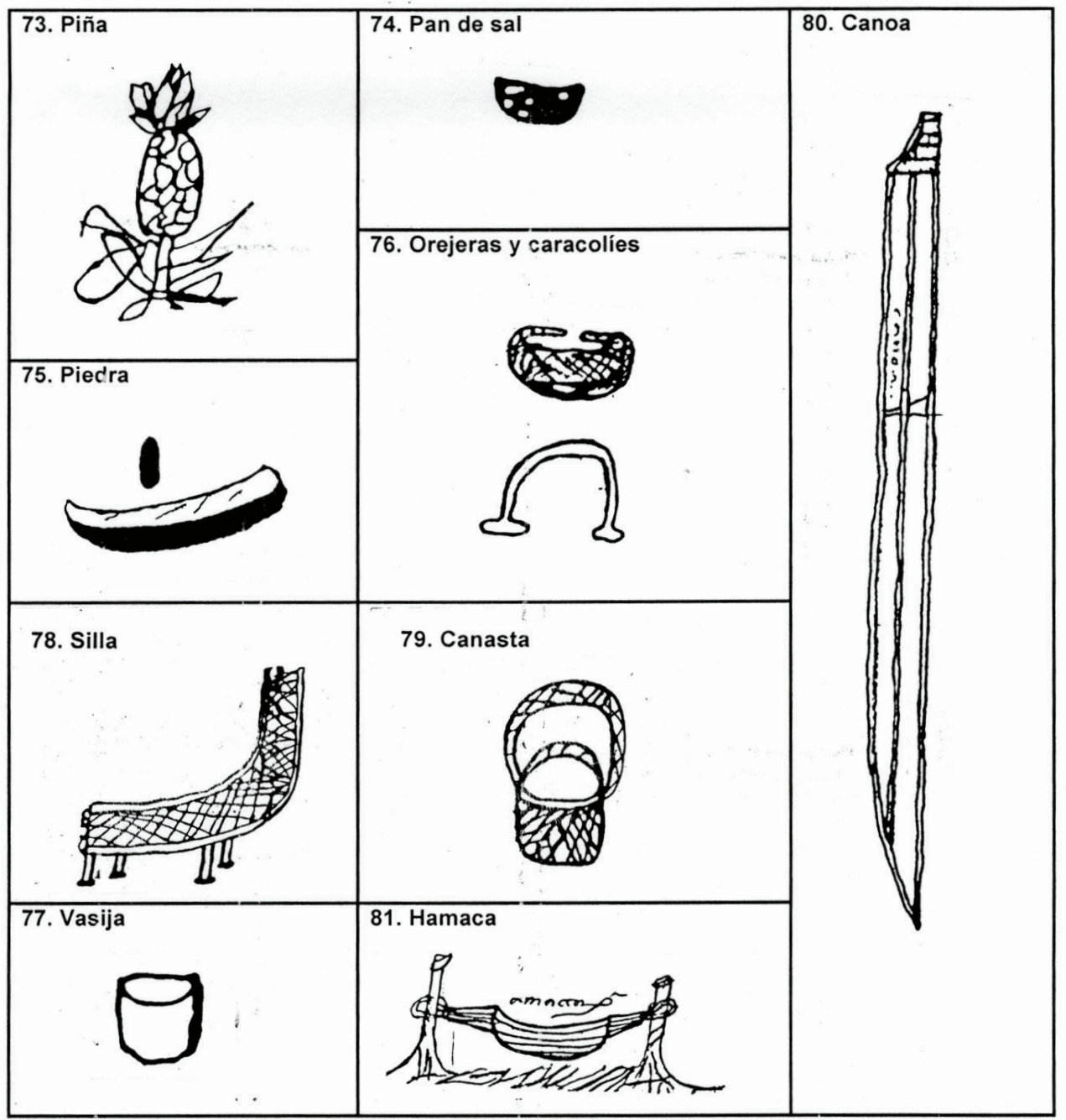

